\title{
Insulin resistance is associated with high plasma ouabain-like immunoreactivity concentration in NIDDM
}

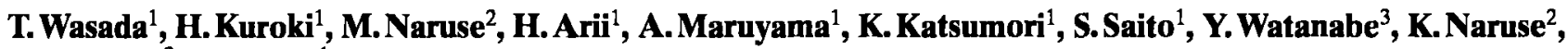 \\ H. Demura ${ }^{2}$, Y. Omori ${ }^{1}$ \\ ${ }^{1}$ Diabetes Center, Tokyo Women's Medical College, Tokyo, Japan \\ ${ }^{2}$ Department of Medicine, Institute of Clinical Endocrinology, Tokyo Women's Medical College, Tokyo, Japan \\ ${ }^{3}$ Mitsubishiyuka BCL, Tokyo, Japan
}

\begin{abstract}
Summary The aim of the present study was to elucidate the pathophysiologic significance of circulating ouabain as a link between insulin resistance (IR) and hypertension (HT) in NIDDM. Euglycaemic $(4.5 \mathrm{mmol} / \mathrm{l})$ hyperinsulinaemic (360-580 pmol/l) clamping was performed using an artificial endocrine pancreas. Plasma ouabain-like immunoreactivity (OLI) was determined by radioimmunoassay using a highly specific antibody to ouabain. HT was defined as systolic blood pressure $>140 \mathrm{~mm} \mathrm{Hg}$ and/or diastolic $>90 \mathrm{~mm} \mathrm{Hg}$ or being treated with antihypertensive agents. The values (mean \pm SEM) of glucose infusion rate (GIR) and plasma OLI were compared among the four groups classified using IR and HT as factors. Group I (IR-/HT-, $\mathrm{n}=15$ ):GIR 7.20 \pm $0.36 \mathrm{mg} \cdot \mathrm{kg}^{-1} \cdot \mathrm{min}^{-1}$, OLI $130.8 \pm 20.9 \mathrm{pmol} / 1$, which was not different from that in eight normal control subjects $\left(7.69 \pm 0.40 \mathrm{mg} \cdot \mathrm{kg}^{-1} \cdot \mathrm{min}^{-1}\right.$ and $142.6 \pm$ $32.3 \mathrm{pmol} / \mathrm{l}$, respectively); Group II (IR-/HT+, $\mathrm{n}=13): \quad 5.89 \pm 0.36 \mathrm{mg} \cdot \mathrm{kg}^{-1} \cdot \mathrm{min}^{-1}, \quad 172.5 \pm 35.0$ $\mathrm{pmol} / \mathrm{l} ; \quad$ Group III $\quad(\mathrm{IR}+/ \mathrm{HT}-, \quad \mathrm{n}=14) \quad 1.91 \pm$
\end{abstract}

$0.28 \mathrm{mg} \cdot \mathrm{kg}^{-1} \cdot \mathrm{min}^{-1}, \quad 576.6 \pm 161.5 \mathrm{pmol} / \mathrm{l} \quad(\mathrm{p}<0.01$ vs Group I and II); Group IV (IR $+/ \mathrm{HT}+, \mathrm{n}=15$ ) $1.79 \pm 0.22 \mathrm{mg} \cdot \mathrm{kg}^{-1} \cdot \mathrm{min}^{-1}, \quad 703.1 \pm 170.1 \mathrm{pmol} / \mathrm{l}$ $(p<0.01$ vs Group I and II), respectively. Six of 57 NIDDM patients studied exhibited very high $(>1500 \mathrm{pmol} / \mathrm{l})$ plasma OLI concentrations, showed marked insulin resistance and were all hypertensive. When analysed as a whole, plasma OLI was negatively correlated with GIR ( $p<0.001)$, but was not correlated with arterial blood pressure. These results demonstrate that plasma concentration of OLI is closely associated with the severity of IR but not with blood pressure elevation. It is, however, possible that in some fraction of NIDDM patients with insulin resistance, the elevation of blood pressure may be causally related to circulating OLI. [Diabetologia (1995) 38: 792-797]

Key words Ouabain-like immunoreactivity, insulin resistance, hypertension, non-insulin-dependent diabetes.
Received: 13 September 1994 and in revised form: 9 December 1994

Corresponding author: Dr. T. Wasada, Diabetes Center, Tokyo Women's Medical College, 8-1 Kawada-cho, Shinjuku-ku, Tokyo 162, Japan

Abbreviations: BSA, Bovine serum albumin; NIDDM, non-insulin-dependent diabetes mellitus; OLI, ouabain-like immunoreactivity; GIR, glucose infusion rate; BMI, body mass index.

Part of this study was presented in the 54th Annual Meeting of the American Diabetes Association, June 11-14, 1994, New Orleans, USA
The mechanism(s) behind hypertension in non-insulin-dependent diabetes mellitus (NIDDM) are poorly understood, but some studies have indicated that sodium retention may play a major role [1-4]. Impaired natriuresis and resultant expansion of extracellular fluid volume have been reported to be associated with hyperinsulinaemia or insulin resistance $[5,6]$. Furthermore, insulin resistance has been shown to accompany the increased sodium and decreased potassium content in erythrocytes [7], and recent evidence also suggests that high $\mathrm{Na}^{+}-\mathrm{Li}^{+}$ countertransport is associated with insulin resistance in patients with essential hypertension [8]. Thus, intracellular sodium accumulation, which in turn cou- 
ples with increased cytosolic free calcium through $\mathrm{Na}^{+}-\mathrm{Ca}^{++}$exchange may cause contraction of resistant vessels or sensitization of vascular smooth muscle cells to vasoconstrictors [9], thereby leading to hypertension [10]. In this context, $\mathrm{Na}^{+} / \mathrm{K}^{+}$-ATPase activity has been reported to be low in a variety of tissues in insulin-resistant states including diabetes [11-14]. Therefore, the reduced activity of sodium pumps $\left(\mathrm{Na}^{+} / \mathrm{K}^{+}\right.$-ATPase $)$may be a key mechanism linking hypertension and insulin resistance in NIDDM. Recently, a potent inhibitor of $\mathrm{Na}^{+} / \mathrm{K}^{+}-\mathrm{AT}$ Pase was isolated from human plasma and found to be indistinguishable from ouabain [15-17], although this novel evidence has been challenged by recent studies $[18,19]$.

In the present study, therefore, we measured plasma ouabain-like immunoreactivity (OLI) concentrations in patients with NIDDM and severe insulin resistance or normal insulin sensitivity to elucidate whether ouabain is involved in the pathophysiology of hypertension associated with insulin resistance.

\section{Subjects and methods}

Subjects. We studied 57 patients with NIDDM and eight healthy control subjects. None of these subjects had overt diabetic complications except early background retinopathy and intermittent proteinuria in some patients. All subjects were in stable health and they had no symptoms of congestive heart failure or oedema of any aetiology. Since NIDDM patients exhibit great variation in their individual sensitivity to insulin (GIR: $0.15-10.0 \mathrm{mg} \cdot \mathrm{kg}^{-1} \cdot \mathrm{min}^{-1}$ ) (Fig. 1), we randomly selected the subjects in the present study from both the highest quartile group (GIR $>5.2 \mathrm{mg} \cdot \mathrm{kg}^{-1} \cdot \mathrm{min}^{-1}$ ) and the lowest quartile group (GIR $<2.20 \mathrm{mg} \cdot \mathrm{kg}^{-1} \cdot \mathrm{min}^{-1}$ ). As shown in Table 1, NIDDM patients were divided into four subgroups according to the degree of insulin resistance and hypertension. Hypertension was defined as average systolic pressure of greater than $140 \mathrm{~mm} \mathrm{Hg}$ and/or average diastolic pressure of greater than $90 \mathrm{~mm} \mathrm{Hg}$ on at least three occasions preceding the euglycaemic clamp study or being treated with antihypertensive drugs. The four subgroups were matched for body mass index (BMI) and fasting blood glucose level. The mean ages ( \pm SEM) of control subjects and Group I were significantly lower than those of other groups, but there was no difference among Groups II, III and IV. Glycaemic control $\left(\mathrm{HbA}_{1 \mathrm{c}}\right)$ and type of treatment for diabetes were similar among the groups. Calcium antagonists were used in 18 of 28 hypertensive patients either alone or in combination with other antihypertensive drugs, followed by beta-blockers in six patients and angiotensin-converting enzyme inhibitors in four patients. Diuretics were used in only two patients. No patient had been given any kind of digitalis treatment.

This study was approved by the Institutional Committee of the Diabetes Center, TWMC, and informed consent was obtained from each of the subjects studied.

Euglycaemic hyperinsulinaemic clamp technique. After an overnight fast and discontinuation of all the medications on the study morning, euglycaemic hyperinsulinaemic clamping was performed using an artificial endocrine pancreas (Nikkiso

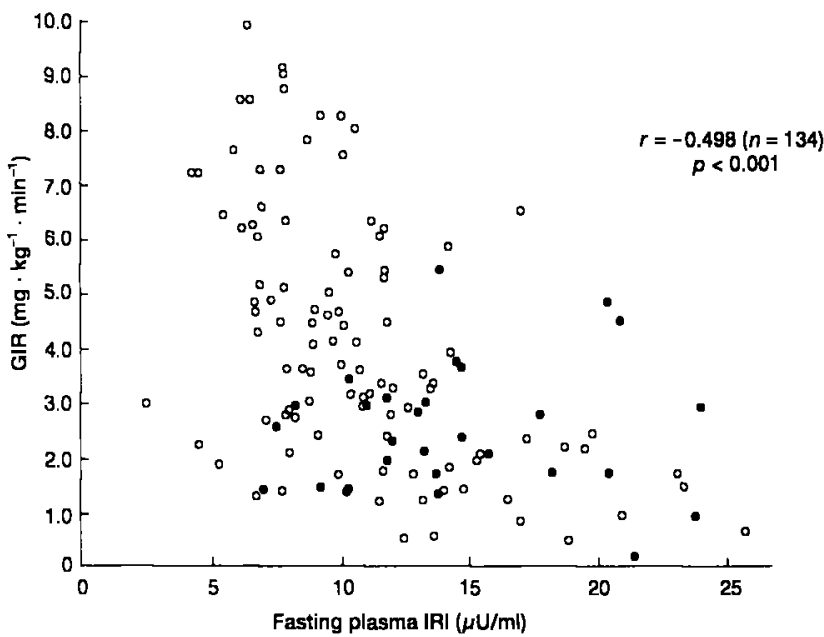

Fig. 1. Correlation between GIR values and fasting plasma IRI concentrations in 134 NIDDM patients without insulin therapy. There is a negative correlation between these two parameters $(r=-0.498, p<0.001)$ and also marked individual variation in GIR levels (GIR: $0.15-10.0 \mathrm{mg} \cdot \mathrm{kg}^{-1} \cdot \mathrm{min}^{-1}$ ). indicates obesity $>27 \mathrm{~kg} / \mathrm{m}^{2}$ (male), $>25 \mathrm{~kg} / \mathrm{m}^{2}$ (female)

STG-22, Nikkiso Co., Tokyo, Japan). A primed-continuous infusion of short-acting insulin (Novolin R, Novo-Nordisk Pharma Co., Copenhagen, Denmark) at $1.12 \mathrm{mU} \cdot \mathrm{kg}^{-1} \cdot \mathrm{min}^{-1}$ was started and peripheral venous plasma glucose was clamped at $4.5 \mathrm{mmol} / \mathrm{l}$ by infusing varying doses of $10 \%$ glucose according to the algorithm originally described by DeFronzo et al. [20]. A steady-state of euglycaemia was maintained over 60$90 \mathrm{~min}$, and the average rate of glucose infusion (GIR, $\mathrm{mg} \cdot \mathrm{kg}^{-1} \cdot \mathrm{min}^{-1}$ ) during the final $30 \mathrm{~min}$ of the study was used as an index for insulin resistance in the whole body. Steadystate plasma insulin concentrations were $498.7 \pm 33.0 \mathrm{pmol} / \mathrm{l}$. Blood samples were drawn for measurements of insulin (IRI), C-peptide (CPR) and OLI before and at appropriate intervals during euglycaemic clamping.

Radioimmunoassay of plasma OLI. Plasma OLI was measured by a recently developed highly specific radioimmunoassay [21]. In brief, blood samples collected in chilled tubes containing $\mathrm{Na}_{2}$ EDTA ( $4 \mathrm{mmol} / \mathrm{l}$ ) were centrifuged at $4^{\circ} \mathrm{C}$, and plasma was stored at $-70^{\circ} \mathrm{C}$ until assayed. One $\mathrm{ml}$ of plasma sample was applied to a Sep-Pak C18 cartridge (Waters Associates, Milford, Mass., USA) and eluted with $75 \%$ ethanol. The extracts were evaporated, lyophilized, and re-dissolved in the assay buffer for radioimmunoassay. The antiserum used in the present assay was raised in New Zealand white rabbits against ouabain (Sigma Chemical Co., St. Louis, Mo., USA) conjugated to bovine serum albumin (BSA). The cross-reactivity of this antibody was $9.2 \%$ with digoxin, and those with BSA, rhamnose, hydrocortisone, and aldosterone were less than $0.007 \%$. The sensitivity of the radioimmunoassay was $0.01 \mathrm{pmol} /$ tube with $50 \%$ displacement at $0.24 \mathrm{pmol} /$ tube. In this radioimmunoassay, the dilution curves of plasma extracts were parallel to the standard curve for authentic ouabain. On the reverse-phase HPLC with a linear gradient of acetonitrile/trifluoroacetic acid, plasma OLI was identified as a single major peak with the retention time corresponding to that of ouabain. The recovery rate of ouabain added to the plasma sample before extraction with Sep-Pak was approximately $95 \%$. The intra- and interassay coefficients of variation at a concentration of $250 \mathrm{pmol} / \mathrm{l}$ were 11.5 and $17.5 \%$, respectively. 
Table 1. Clinical and metabolic characteristics of the groups of study subjects

\begin{tabular}{|c|c|c|c|c|c|}
\hline \multirow[b]{2}{*}{$\begin{array}{l}\text { Group } \\
\text { (IR/HT) }\end{array}$} & \multicolumn{4}{|c|}{ NIDDM patients } & \multirow{2}{*}{$\begin{array}{l}\text { Normal control } \\
\text { subjects }\end{array}$} \\
\hline & $\begin{array}{l} \\
(-I-)\end{array}$ & $\begin{array}{l}\text { II } \\
(-l+)\end{array}$ & $\begin{array}{l}\text { III } \\
(+/-)\end{array}$ & $\begin{array}{l}\text { IV } \\
(+/+)\end{array}$ & \\
\hline$n$ (male: female) & $15(12: 3)$ & $13(9 * 4)$ & $14(10: 4)$ & $15(10: 5)$ & $8(4: 4)$ \\
\hline Age (years) & $46.1 \pm 2.3^{\mathrm{a}}$ & $52.9 \pm 2.6^{\mathrm{ab}}$ & $54.2 \pm 2.8^{\mathrm{ab}}$ & $61.3 \pm 2.8^{\mathrm{ab}}$ & $37.8 \pm 4.7$ \\
\hline $\mathrm{BMI}\left(\mathrm{kg} / \mathrm{m}^{2}\right)$ & $22.0 \pm 0.7$ & $24.2 \pm 1.0^{c}$ & $23.2 \pm 0.8$ & $23.8 \pm 0.9$ & $20.8 \pm 1.0$ \\
\hline Duration (years) & $5.6 \pm 1.6$ & $4.0 \pm 0.9$ & $6.6 \pm 1.6$ & $9.2 \pm 1.9^{d}$ & \\
\hline $\mathrm{FPG}(\mathrm{mmol} / \mathrm{l})$ & $7.9 \pm 0.9$ & $7.0 \pm 0.6$ & $7.7 \pm 0.5$ & $9.2 \pm 1.1$ & $4.7 \pm 0.1$ \\
\hline $\mathrm{HbA}_{1}(\%)$ & $9.2 \pm 1.0$ & $7.7 \pm 0.5^{\mathrm{e}}$ & $9.5 \pm 0.6$ & $9.1 \pm 0.5$ & $5.4 \pm 0.2$ \\
\hline $\mathrm{SBP}(\mathrm{mm} \mathrm{Hg})$ & $118.4 \pm 2.9^{f}$ & $147.7 \pm 4.4$ & $124.6 \pm 3.0^{\mathrm{f}}$ & $154.6 \pm 5.5$ & $114.5 \pm 3.5$ \\
\hline $\mathrm{DBP}(\mathrm{mm} \mathrm{Hg})$ & $75.4 \pm 1.5^{\mathrm{g}}$ & $91.2 \pm 2.5$ & $72.9 \pm 1.7^{\mathrm{B}}$ & $87.8 \pm 2.8$ & $69.2 \pm 2.0$ \\
\hline FIRI $(\mu \mathrm{U} / \mathrm{ml})$ & $6.8 \pm 0.9$ & $7.9 \pm 1.2$ & $11.8 \pm 1.1^{\mathrm{hi}}$ & $15.6 \pm 2.9^{\mathrm{hi}}$ & $6.1 \pm 1.0$ \\
\hline $\mathrm{GIR}\left(\mathrm{mg} \cdot \mathrm{kg}^{-1} \cdot \mathrm{min}^{-1}\right)$ & $7.20 \pm 0.36^{\mathrm{j}}$ & $5.89 \pm 0.36^{\mathrm{k}}$ & $1.91 \pm 0.28^{1}$ & $1.79 \pm 0.22^{1}$ & $7.69 \pm 0.40$ \\
\hline Micro/Macro-AU & $4 / 15$ & $3 / 13$ & $3 / 14$ & $5 / 15$ & \\
\hline \multicolumn{6}{|l|}{ Treatment } \\
\hline Diet alone & $6 / 15$ & $7 / 13$ & $7 / 14$ & $6 / 15$ & \\
\hline OHA & $4 / 15$ & $1 / 13$ & $4 / 14$ & $4 / 15$ & \\
\hline Insulin & $5 / 15$ & $5 / 13$ & $3 / 14$ & $5 / 15$ & \\
\hline Anti-HT & & $7 / 13$ & & $14 / 15^{\mathrm{m}}$ & \\
\hline
\end{tabular}

Values are means \pm SEM. IR, insulin resistance; HT, hypertension; BMI, body mass index; FPG, fasting plasma glucose; SBP, systolic blood pressure; DBP, diastolic blood pressure; FIRI, fasting plasma insulin; GIR, glucose infusion rate, Micro/Macro-AU, microalbuminuria (30-300 $\mathrm{mg} /$ day) or macroalbuminuria ( $>300 \mathrm{mg} /$ day); OHA, oral hypoglycaemic agents; Anti-HT, antihypertensive agents; IR-/HT+, for exam-

\section{Statistical analysis}

Data were expressed as means \pm SEM and statistically analysed by the Mann-Whitney test, the chi-square test, and the non-linear or linear regression analysis, as appropriate. The level of significance was set at $p<0.05$.

\section{Results}

Plasma OLI concentrations were compared among the groups (Fig.2). The mean level for eight normal glucose-tolerant subjects was $142.6 \pm 32.3 \mathrm{pmol} / \mathrm{l}$. The highest level was found in the Group IV with both insulin resistance and hypertension (703.1 \pm $170.1 \mathrm{pmol} / \mathrm{l})$. The lowest level was in Group I with neither insulin resistance nor hypertension (130.8 \pm $20.9 \mathrm{pmol} / \mathrm{l}$ ), and was not significantly different from that in the normal control group. Those in Groups II and III with either hypertension or insulin resistance were intermediate between these two values $(172.5 \pm 35.0, \quad 576.6 \pm 161.5 \mathrm{pmol} / \mathrm{l}$, respectively). Very high plasma OLI levels (greater than 1500 $\mathrm{pmol} / \mathrm{l}$ ) were found in six patients, all of whom were in the insulin-resistant groups (Groups III and IV). The clinical features of these six patients are presented in Table 2. The mean plasma OLI level was elevated in the hypertensive groups compared with the normotensive counterpart, i.e. Group I vs II, and Group III vs IV, but the differences were not statistically significant in either pair. There was an inverse ple indicates the absence of IR and the presence of HT; ${ }^{a} p<0.05-0.001$ vs control; ${ }^{\mathrm{b}} p<0.05-0.001$ vs I; ${ }^{\mathrm{c}} p<0.05$ vs control; ${ }^{d} p<0.05$ vs II; ${ }^{\mathrm{e}} p<0.05$ vs III and IV; ${ }^{\mathrm{f}} p<0.001$ vs II and IV; ${ }^{\mathrm{g}} p<0.001$ vs II and IV; ${ }^{\mathrm{h}} p<0.01$ vs control; ${ }^{\mathrm{i}} p<0.05$ vs II; i $p<0.02$ vs II; ${ }^{\mathrm{k}} p<0.005$ vs control; ${ }^{\mathrm{l}} p<0.001$ vs I, II and control, ${ }^{\mathrm{m}} p<0.05$ vs II

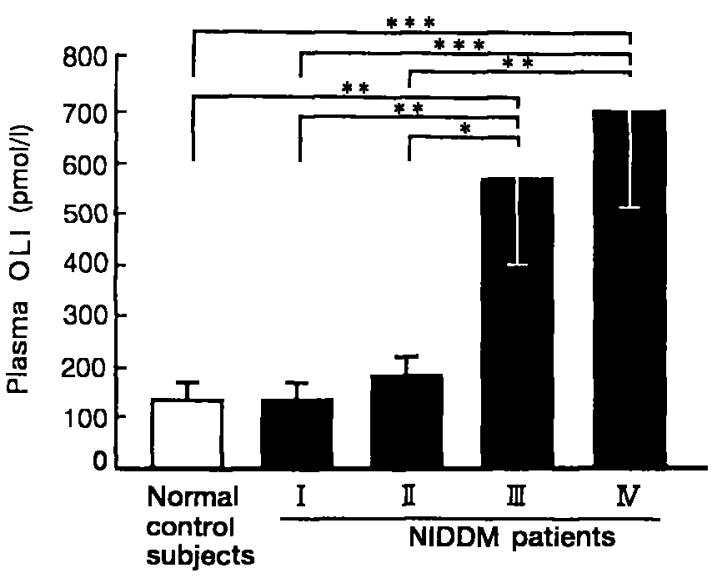

Fig. 2. Plasma OLI concentrations in normal control subjects and NIDDM patients. NIDDM patients were divided into four subgroups by the presence $(+)$ or absence $(-)$ of insulin resistance (IR) and hypertension (HT): Group I (IR-/HT-), II (IR-/HT+), III (IR+/HT-), and IV (IR+/HT+). The difference was significant between Group I and II and Group III and IV, while those between normal control subjects and Group I and II, between Group I and Group II, and between Group III and Group IV were not significant. ${ }^{*} p<0.05$; ** $p<0.01 ; * * * p<0.001$

correlation between plasma OLI levels and the GIR values when all subjects were combined $(p<0.001$, $n=65$, Fig. 3 ), and even when the extremely high values of OLI $(>1500 \mathrm{pmol} / \mathrm{l})$ were excluded $(p<0.01$, $n=59$ ). However, no correlation was found between plasma OLI and blood pressure. 
Table 2. Clinical profile of patients with very high (>1500 pmol/l) plasma levels of OLI

\begin{tabular}{|c|c|c|c|c|c|c|}
\hline & F.I. & Y.I. & N.T. & T.W. & H.T. & K.H. \\
\hline $\begin{array}{l}\text { Age (years): } \\
\text { Sex (male/female) }\end{array}$ & 71 :Female & 59:Male & $65:$ Female & 64:Female & $60:$ Female & 63:Female \\
\hline $\mathrm{BMI}\left(\mathrm{kg} / \mathrm{m}^{2}\right)$ & 23.4 & 25.6 & 24.7 & 21.7 & 26.3 & 21.9 \\
\hline $\mathrm{HbA}_{1 \mathrm{C}}(\%)$ & 10.0 & 6.0 & 9.9 & 10.6 & 10.1 & 12.1 \\
\hline Hypertension & + & + & + & + & + & + \\
\hline Drug therapy & $\begin{array}{l}\mathrm{Ca}^{++} \text {-ant. } \\
\text { diuretic }\end{array}$ & $\begin{array}{l}\text { none } \\
\text { (low salt diet) }\end{array}$ & $\begin{array}{l}\mathrm{Ca}^{++} \text {-ant. } \\
\text { ACE-inh. } \\
\text { diuretic }\end{array}$ & $\begin{array}{l}\mathrm{Ca}^{++} \text {-ant. } \\
\text { diuretic }\end{array}$ & $\mathrm{Ca}^{++}$-ant. & $\begin{array}{l}\text { none } \\
\text { (low salt diet) }\end{array}$ \\
\hline $\operatorname{GIR}\left(\mathrm{mg} \cdot \mathrm{kg}^{-1} \cdot \mathrm{min}^{-1}\right)$ & 1.21 & 1.88 & 1.78 & 0.58 & 1.69 & 0.77 \\
\hline PRA (ng $\left.\cdot \mathrm{ml}^{-1} \cdot \mathrm{h}^{-1}\right)$ & 2.2 & 2.4 & 1.7 & & 0.8 & 1.1 \\
\hline $\operatorname{PAC}(\mathrm{ng} / \mathrm{dl})$ & 7.7 & 5.9 & 4.8 & & 4.7 & 5.0 \\
\hline Diabetes therapy & SU & Diet & Insulin & SU & SU & Insulin \\
\hline Past medical history & & & OMI & $\mathrm{CHF}$ & OMI & \\
\hline
\end{tabular}

Hypertension was defined by systolic blood pressure $>140 \mathrm{~mm} \mathrm{Hg}$ and diastolic $>90 \mathrm{~mm} \mathrm{Hg}$ or drug treatment. PRA, Plasma renin activity (normal: $0.5-3.0 \mathrm{ng} \cdot \mathrm{ml}^{-1} \cdot \mathrm{h}^{-1}$ );

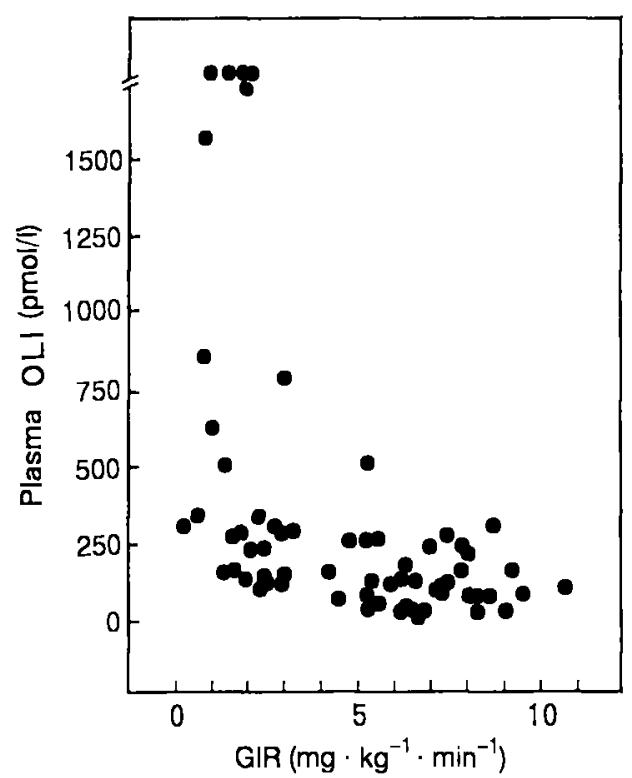

Fig. 3. Correlation between GIR and plasma OLI levels in all subjects studied (eight normal control subjects and 57 patients with NIDDM). A non-linear regression analysis showed a significant relationship between plasma OLI (Y) and GIR (X): $\mathrm{Y}=562.4-124.5 \mathrm{X}+7.8 \mathrm{X}^{2}, r=0.528(p<0.0001)$. When the extremely high values of OLI ( $>1500 \mathrm{pmol} / \mathrm{l}$ ) were excluded, a linear negative correlation was found between them $(r=-0.487, p<0.01, n=59)$

\section{Discussion}

The present study demonstrated that plasma concentrations of OLI are significantly higher in insulin-resistant NIDDM patients than in insulin-sensitive patients or normal glucose-tolerant subjects, while there was no difference between the latter two groups. Furthermore, plasma OLI concentration showed a significant negative correlation with the GIR value, when analysed in each subject. To our
PAC, plasma aldosterone concentration (normal: $2.2-15 \mathrm{ng} /$ dl); SU, sulfonylurea; OMI, old myocardial infarction; CHF, congestive heart failure

knowledge, the relationship between insulin resistance and plasma levels of OLI has not been explored directly in patients with NIDDM.

Our values of plasma OLI concentration were comparable to those reported by other investigators $[22,23]$. Hamlyn's group [22] reported that the plasma ouabain concentration ranges from below 200 to $700 \mathrm{pmol} / \mathrm{l}$ in most normal individuals, but in some patients to as high as $10 \mathrm{nmol} / \mathrm{l}$ or even higher. Similarly, a more than 50-fold variation in plasma levels of OLI was found in the present group, and in six patients plasma OLI levels exceeded more than $1500 \mathrm{pmol} / \mathrm{l}$. These patients shared severe insulin resistance and hypertension, but otherwise there was no clinical marker that characterized this particular subgroup of patients. Since the concentrations of ouabain normally present in the circulation have been demonstrated to be active in modulating vascular contractility [24], this may have pathophysiologic implications in hypertension associated with insulin resistance.

Andronico et al. [25] estimated plasma concentrations of immunoreactive "endogenous digoxin-like factor (EDLF)", in 14 hypertensive and 12 normotensive subjects with obesity and glucose intolerance. In their studies, hypertensive subjects showed higher plasma EDLF levels and lower plasma glucose/insulin ratio than normal subjects, indicating a possible association between plasma EDLF levels and the degree of insulin resistance. The results of the present study are well in agreement with their findings. However, insulin resistance can be more reliably evaluated by the euglycaemic hyperinsulinaemic clamp method, and plasma digitalis-like substance can now be determined more directly with specific radioimmunoassay for ouabain. Our findings, therefore, provide direct and better evidence to support the close 
relationship between plasma OLI and insulin resistance.

In our study, however, the relationship between hypertension and plasma OLI was not significant. Plasma OLI tended to be higher in the hypertensive group, but the difference was not statistically significant between the groups with comparable insulin resistance. Therefore, plasma OLI could not be concluded to play a role in the development of hypertension from the results of the present study. However, it has since been reported that plasma OLI levels are lowered after antihypertensive treatment in patients with essential hypertension [21], plasma levels of OLI in our patients could be underestimated, and, thus, may obscure the possible differences between the groups with and without hypertension.

Devynck et al. [26] reported that plasma potency of EDLF measured by its interfering activity with ${ }^{3} \mathrm{H}$-ouabain binding to erythrocyte sodium pumps was significantly correlated with the rate of urinary sodium output in patients with essential hypertension. Therefore, elevated plasma OLI may be part of a compensatory mechanism for impaired natriuresis secondary to insulin resistance. This is in accordance with the observations that salt-loading and expansion of plasma volume induce a rise in plasma levels of ouabain in experimental animals and humans [27], and that elevated levels of ouabain are likely to be found in essential hypertension characterized by suppressed plasma renin activity $[28,29]$.

Ouabain possibly opposes the ability of insulin to stimulate tubular reabsorption of sodium in the kidney. On the other hand, in the cardiovascular muscle cells, ouabain causes an increase in intracellular sodium concentration, which in turn reduces the $\mathrm{Na}^{+} /$ $\mathrm{Ca}^{++}$countertransport activity and results in increased cytosolic free calcium and decreased free magnesium, thus leading to potentiation of cardiovascular reactivity $[9,10,30]$. It has been reported that $\mathrm{Na}^{+} / \mathrm{K}^{+}$-ATPase activity is reduced in a variety of tissues in insulin-resistant states; human essential hypertension [11, 12], obesity [13], and experimental models of diabetes [14]. Therefore, our findings may partly explain the reduction of $\mathrm{Na}^{+} / \mathrm{K}^{+}$-ATPase activity accompanying insulin resistance. Moreover, reduced sodium pump activity has been proposed to exaggerate neural stimulation and norepinephrine overflow [31] which, together with increased peripheral vascular resistance, might explain the development of hypertension associated with insulin resistance. Recently, the parenteral administration of ouabain over a 4- to 6-week period was reported to cause chronic hypertension in rats [32]. However, recent studies cast doubts about the presence of ouabain in human plasma and its pathophysiological role in the development of hypertension $[18,19]$. Therefore, further efforts should be made to elucidate whether an endogenous natriuretic and hypertensinogenic sub- stance is a true ouabain, and whether ouabain could be a link between insulin resistance and hypertension in NIDDM.

\section{References}

1. De Chatel R, Weidmann P, Flammer J et al. (1977) Sodium, renin, aldosterone, catecholamines, and blood pressure in diabetes mellitus. Kidney Int 12: 412-421

2. O'Hare JA, Ferris JB, Brady D, Twomey B, O'Sullivan DJ (1985) Exchangeable sodium and renin in hypertensive diabetic patients with and without nephropathy. Hypertension 7 [Suppl II]: 43-48

3. Weidmann P, Beretta-Piccoli C, Trost BN (1985) Pressor factors and responsiveness in hypertension accompanying diabetes mellitus. Hypertension 7 [Suppl II]: 33-42

4. Feldt-Rasmussen B, Mathiesen ER, Deckert T et al (1987) Central role for sodium in the pathogenesis of blood pressure changes independent of angiotensin, aldosterone and catecholamines in type 1 (insulin-dependent) diabetes mellitus. Diabetologia 30: 610-617

5. DeFronzo RF (1981) The effect of insulin on renal sodium metabolism, a review with clinical implications. Diabetologia 21: 165-171

6. Halkin H, Modan M, Shefi M, Almog S (1988) Altered erythrocyte and plasma sodium and potassium in hypertension, a facet of hyperinsulinemia. Hypertension 11: 71-77

7. Modan M, Halkin H, Almog S et al. (1985) Hyperinsulinemia, a link between hypertension, obesity and glucose intolerance. J Clin Invest 75: 809-817

8. Doria A, Fioretto P, Avogaro A et al. (1991) Insulin resistance is associated with high sodium-lithium countertransport in essential hypertension. Am J Physiol 261: E684-E691

9. Sowers JF, Khoury S, Standley P, Zemel P (1991) Mechanisms of hypertension in diabetes. Am J Hypertens 4: 177182

10. Resnick LM (1993) Ionic basis of hypertension, insulin resistance, vascular disease, and related disorders: the mechanism of "syndrome X". Am J Hypertens 6: 123 S-134S

11. Garay RP, Dagher G, Permollet MG, Devynck MA, Meyer $P$ (1980) Inherited defect in $\mathrm{Na}^{+}-\mathrm{K}^{+}$cotransport system in erythrocytes from essential hypertensive patients. Nature (Lond) 284: 281-283

12. Hilton PJ (1986) Cellular sodium transport in essential hypertension. N Engl J Med 314: 212-219

13. De Luise M, Blackman GL, Flier JS (1980) Reduced activity of the red-cell sodium-potassium pump in human obesity. N Engl J Med 303: 1017-1022

14. Cohen MP, Dasmahapatra A, Shapiro E (1985) Reduced glomerular sodium/potassium adenosine-triphosphatase activity in acute streptozocin diabetes and its prevention by oral sorbinil. Diabetes 34: 1071-1074

15. Ludens JH, Clark MA, DuCharme DW et al. (1991) Purification of an endogenous digitalislike factor from human plasma for structural analysis. Hypertension 17: 923-929

16. Mathews WR, DuCharme DW, Hamlyn JM et al. (1991) Mass spectral characterization of an endogenous digitalislike factor from human plasma. Hypertension 17: 930-935

17. Hamlyn JM, Blaustein MP, Bova S et al. (1991) Identification and characterization of a ouabain-like compound from human plasma. Proc Natl Acad Sci USA 88: 6259-6263

18. Rose AM, Valdes R Jr (1994) Understanding the sodium pump and its relevance to disease. Clin Chem 40: 1674 1685 
19. Doris PA, Jenkins LA, Stocco DM (1994) Is ouabain an authentic endogenous mammalian substance derived from the adrenal? Hypertension 23: 632-638

20. DeFronzo RA, Tobin JD, Andres R (1979) Glucose clamp technique; a method for quantifying insulin secretion and resistance. Am J Physiol 237: E214-E223

21. Naruse K, Naruse M, Tanabe A et al. (1994) Does plasma immunoreactive ouabain originate from the adrenal gland? Hypertension 23 [Suppl I]: I-102-I-105

22. Hamlyn JM, Manunta P (1992) Ouabain, digitalis-like factors and hypertension. J Hypertens 10 [Suppl 7]: S 99-S 111

23. Manunta P, Hamilton BS, Pruce E, Hamlyn JM (1992) High dietary sodium raises plasma levels of ouabain in normal man. J Hypertens 10 [Suppl 6]: 96 (Abstract)

24. Blaustein MP (1993) Physiological effects of endogenous ouabain: control of intracellular $\mathrm{Ca}^{++}$stores and cell responsiveness. Am J Physiol 264: C1367-C1387

25. Andronico G, Mule G, Mangano MT et al. (1992) Insulin resistance and endogenous digoxin-like factor in obese hypertensive patients with glucose intolerance. Acta Diabetol 28: 203-205

26. Devynck MA, Pernollet MG, Meyer P (1987) Endogenous digitalis-like compounds in essential and experimental hypertension. Int J Rad Appl Instrum (B) 14: 341-352
27. Gruber KA, Whitaker JM, Buckalew VM Jr (1980) Endogenous digitalis-like substance in plasma of volume-expanded dogs. Nature 287: 1-3

28. Haddy FJ, Pamnani MB (1985) Evidence for a circulating endogenous $\mathrm{Na}^{+} / \mathrm{K}^{+}$pump inhibitor in low renin hypertension. Fed Proc 44: 2789-2794

29. Hamlyn JM, Levinson PD, Ringel R et al. (1985) Relationships among endogenous digitalis-like factors in essential hypertension. Fed Proc 44: 2782-2788

30. Blaustein MP, Ashida T, Goldman WF, Wier WG, Hamlyn JM (1986) Sodium/calcium exchange in vascular smooth muscle; a link between sodium metabolism and hypertension. Ann NY Acad Sci 488: 199-216

31. Tsuda K, Tsuda S, Shima H, Masuyama Y (1989) Facilitatory effects of ouabain and digitalis-like substance on adrenergic transmission in hypertension. Am J Hypertens 2: 465-467

32. Yuan C, Manunta $P$, Chen S, Hamlyn JM, Pamnani MB (1992) Hypertension induced by chronic ouabain administration in rats (Abstract 48) FASEB J 6: A 495 